\title{
Religious Self-definition, Mass Attendance, Importance of God, and Hopelessness among Spanish Undergraduates
}

\section{Autodefinición Religiosa, Asistencia a Misa, Importancia de Dios y Desesperanza en Universitarios Españoles}

\author{
Joaquín García-Alandete ${ }^{1}$, Eva Rosa Martínez ${ }^{1}$ y José Francisco Gallego-Pérez ${ }^{2}$ \\ ${ }^{1}$ Departament of Methodology, Basic Psychology and Social Psychology. Faculty of Psychology and Health Sciences. Catholic \\ University of Valencia. Valencia, Spain. ${ }^{2}$ Departament of Personality, Assessment and Treatment. Faculty of Psychology and \\ Health Sciences. Catholic University of Valencia. Valencia, Spain.
}

Disponible online 31 de diciembre de 2011

\begin{abstract}
The aim of this work was to examine the relationship between religious self-definition, attending Mass, the importance of God, and hopelessness under the hy-pothesis that these religious variables and hopelessness are negatively related. The par-ticipants were 273 Spanish undergraduates who were incidentally recruited. and who completed three religious items and the Spanish version of a Hopelessness Scale. The Chi-squared test and Bonferroni test were used in the statistical analysis. The results indicate that there were no statistically significant differences between the religious self-definition and attending Mass groups in relation to hopelessness, whereas there were differences between groups in the variable importance of God; this is not consis-tent with the findings of previous studies. We discuss the limitations of the study, offer suggestions for future research, and indicate the need to distinguish between the diverse aspects of religiosity to better explain their implications regarding hopelessness.
\end{abstract}

Keywords: Religiosity; Hopelessness; Spanish Undergraduates.

El objetivo de este trabajo es analizar la relación entre la autodefinición religiosa, la asistencia a Misa, la importancia de Dios y la desesperanza. La hipótesis afirma que las variables religiosas y la desesperanza están negativamente relacionadas. Participan 273 estudiantes universitarios españoles reclutados incidentalmente, los cuales cumplimentan tres ítems religiosos y una versión española de la Escala de Desesperanza. Se utilizan los estadísticos Chi-Cuadrado y Bonferroni. Los resultados indican que los distintos grupos de autodefinición religiosa y de asistencia a Misa no se relacionan con diferencias significativas en desesperanza, mientras que en la variable importancia de Dios sí existen diferencias entre grupos, diferencias que no se ajustan a lo hallado en estudios anteriores. Se observan las limitaciones del estudio, se ofrecen sugerencias para futuras investigaciones y la necesidad de distinguir entre los distintos aspectos de la religiosidad, con el fin de precisar mejor sus implicaciones sobre la desesperanza.

Palabras clave: Religiosidad; Desesperanza; Universitarios Españoles.

Correspondence concerning this article should be addressed to: Joaquín García-Alandete. Departament of Methodology, Basic Psychology and Social Psychology. Fa-culty of Psychology and Health Sciences. Catholic University of Valencia. C/ Guillem de Castro, 94. 46001-Valencia, Spain. E-mail: ximo.garcia@ucv.es. Authors’ E-mails: Eva Rosa Martínez: eva.rosa@ucv.es, José Francisco Gallego-Pérez: francisco.gallego@ucv.es. 
From his research with depressed patients, Beck (1964) developed the cognitive theory of depression. In these patients, Beck found negative and dysfunctional thoughts, consistently and systematically. Depressed patients often have a negative view of themselves, the world, and the future. This style of thinking called the «negative cognitive triad» (Beck, 1967, 1970). Negative cognitive triad involves three patterns in the individual's idiosyncratic vision: himself, his future and his experiences (negative view of himself: patient tends to be underestimated and criticized with negative self-attributions; negative interpretation of his experiences: patient views the world with insurmountable obstacles and characterized by exaggerated claims, and he feels defeated and frustrated; negative view about the future: patient anticipates that his current difficulties and sufferings will continue indefinitely). In other words, the hopeless persons believe that: 1) they can never get ahead for themselves, 2) they will never succeed in what they attempt, 3) they can never achieve important goals, and 4) they can never solve the various problems facing in life.

Beck, Kovacs \& Weissman (1975) developed the theory of hopelessness to explain the suicidal tendency of some patients, finding that the loss of hope was the catalyst. As indicated above, hopelessness is characterized by cognitive distortions in which personal experiences are negatively viewed, and believes that attempts to achieve goals will end in failure. Hopelessness is a powerful predictor of suicidal trends, modulating the relationship between depression and suicidal behavior (Beck, Brown, Berchick, Stewart \& Steer, 1990; Beck \& Steer, 1993; Beck, Steer, Beck \& Newman, 1993; Beck, Steer, Kovacs \& Garrison, 1985; Conner, Duberstein, Conwell, Seidlitz \& Caine, 2001; Esposito, Spirito, Boergers \& Donaldson, 2003; Quintanilla, Haro, Flores, Celis \& Valencia, 2003).

Some studies report a negative relationship between religiosity (religious practice, religious commitment, and shared beliefs) and hopelessness, and other variables associated with it, such as depression, stress, and suicide (Ellison, Boardman, Williams \& Jackson, 2001; Garrison, Marks, Lawrence \& Braun, 2004; Grey, 2005; Hammermeister, Flint, Havens \& Peterson, 2001; Hill, Angel, Ellison \& Angel, 2005; Lester \& Francis, 1993; Murphy, 1999; Simonson, 2008; Smith, McCullogh \& Poll, 2003). Religiosity may inhibit the development of hopelessness thoughts, and is a powerful factor related to both physical and mental health, life satisfaction, purpose in life, and to psychological and subjective well-being (Clarke \& Kissane, 2002; Dalgalarrondo, 2006; George, Larson, Koenig \& McCullogh, 2000; Koenig, 1997, 2007; Moreira-Almeida, Lotufo Neto \& Koenig, 2006; Pargament, 1997; Pargament, Koenig \& Perez, 2000).

In this regard, the aim of this work is to analyze the relationship between religion and hopelessness, posing the hypothesis that it is negative. We use the concept of religion that offers
Pargament (1997), as a broad domain that includes individual and institutional expressions, serves a variety of purposes, and may play potentially helpful and/or harmful roles in people's lives.

\section{Participants \\ Method}

The sampling was incidental, participating voluntarily 273 students enrolled in a private, catholic university in the city of Valencia (Spain). The group included 87 men and 186 women, ranging in age from 18 to 25 years $(M=20.78, S D=1.85)$ who collectively, during school hours and under supervision of the authors of this study, a protocol that included the Spanish version of Hopelessness Scale, ensuring anonymity and confidentiality of the results, informing the voluntary nature of participation and re-solve the questions on procedure. Participants were not informed about the purpose of the study to avoid insincere responses and minimize the effect of social desirability.

All participants are students at a Catholic university, and all of them are Catholics by baptism, although not all of them are practicing believers. The distribution of participants in the religious variables is shown in Table 1.

Table 1

Distribution of the participants in the groups of the religious variables.

\begin{tabular}{llcc}
\hline Religious variable & Groups & $N$ & $\%$ \\
\hline Religious Self-definition & Practicing Catholic & 32 & 11.7 \\
& Non-practicing Catholic & 109 & 39.9 \\
& Indifferent & 78 & 28.6 \\
& Atheist & 54 & 19.8 \\
Mass Attendance & Often & 48 & 17.6 \\
& Occasionally & 87 & 31.9 \\
Importance of God & Never & 138 & 50.5 \\
& A lot & 14 & 5.1 \\
& Enough & 33 & 12.1 \\
& Little & 144 & 52.7 \\
& None & 82 & 30 \\
& & 273 & 100 \\
\hline
\end{tabular}

Most of the participants identified themselves as Nonpracticing Catholics, followed by Indifferent, Atheists, and Practicing Catholics. Regarding Mass attendance, most of the participants declare that 'Never' attend to Mass, followed by 'Occasionally', and 'Often'. Likewise, most of the participants consider God of Little importance in their lives, followed by 'None', 'Enough', and 'A lot'. So, most of the participants, although they are students in a Catholic University, are nonpracticing, never attend to Mass, and believe that God is unimportant.

None of the participants claimed to be believers of other religious denomination that was not Catholic. Consequently, 
data from this work are always relative to Catholics, when referring to believers, whether they are practicing as if they are not.

\section{Instrument}

Hopelessness was assessed by means of a Spanish version of Hopelessness Scale (HS) (Beck, Weissman, Lester \& Trexler, 1974), by Viñas et al. (2004). This scale measures negative expectations about future and personal welfare, abilities to resolve difficulties and to achieve success, and hopelessness as related to suicidal syndrome. Total scores range from 0 to 20 , with higher scores indicating a greater degree of hopelessness (suicide risk): Null-minimum (0-3 scores); Slight (4-8 scores); Moderate (9-14 scores); High (15-20 scores). The Spanish version used in this work showed an acceptable internal consistency $(\alpha=.79)$.

The religiosity is measured by means of three variables, considered as categorical: Religious self-definition (Practicing Catholic; Non-practicing Catholic; Indifferent; Atheist), Mass attendance (Often: once at week or more; Occasionally: sometimes in one year; Never), and Importance of God in one's life (None; Little; Enough; A lot).

\section{Procedure and statistical analysis}

Participants completed the study measures as a voluntary, in-class activity, under the supervision of trained collaborators. They were provided a protocol containing items about sex, age, the three religious items, and the HS. Protocols were completed in approximately 30 minutes.

Data were inputted into a SPSS 12.0 sheet for Windows in order to discard invalid or incomplete questionnaires. Statistical analysis included the Chi-Square test and Bonferroni test for differences of religion on hopelessness, and the $t$ test for independent samples to test whether gender differences are significant in hopelessness.

\section{Results}

Participants reported a relatively low level of hopelessness $(M=3.27, S D=2.75)$. Table 2 shows the distribution of the participants in terms of suicidal risk levels.

Table 2

Distribution of participants by level of suicide risk.

\begin{tabular}{lcc}
\hline Suicide Risk & $N$ & $\%$ \\
\hline Null-minimum & 165 & 60.4 \\
Slight & 95 & 34.8 \\
Moderate & 11 & 4 \\
High & 2 & .7 \\
Total & 273 & 100 \\
\hline
\end{tabular}

The mean ranks of the religious variables in hopelessness are shown in Table 3. Nonparametric Kruskal-Wallis test was used.
Table 3

Mean ranks of the religious variables on hopelessness.

\begin{tabular}{llc}
\hline Variables & & Mean Rank \\
\hline Religious Self-definition & Practicing Catholic & 148.19 \\
& Non-practicing Catholic & 142.33 \\
& Indifferent & 130.54 \\
& Atheist & 128.94 \\
Mass Attendance & Occasionally & 146.16 \\
& Often & 144.89 \\
& Never & 128.49 \\
Importance of God & Enough & 162.83 \\
& Little & 142.36 \\
& None & 123.98 \\
& A lot & 97.21 \\
\hline
\end{tabular}

Note: Means are ranked from highest to lowest, in all religious variables.

Differences in religious self-definition and Mass attendance on the HS total score were not significant. On the contrary, differences in the importance of God were significant (Table 4).

Table 4

Chi-square, degrees of freedom, and significance values of the religious variables on hopelessness.

\begin{tabular}{lcc}
\hline Variables & $\chi^{2}($ g.l.) & $p$ \\
\hline Religious Self-definition & $2.284(3)$ & .516 \\
Mass Attendance & $3.339(2)$ & .188 \\
Importance of God & $10.246(3)$ & $.017 *$ \\
\hline Note $: p<.05$ & &
\end{tabular}

Note: $p<.05$

A Bonferroni test showed that differences between EnoughNone categories, and Enough-A lot categories were significant (Table 5).

Table 5

Differences between groups on Importance of God.

\begin{tabular}{|c|c|c|c|c|c|c|}
\hline \multirow{2}{*}{\multicolumn{2}{|c|}{$\begin{array}{l}\text { Importance of } \\
\text { God }\end{array}$}} & \multirow{3}{*}{$\begin{array}{c}\text { Mean } \\
\text { Diffference } \\
\text { Límite inferior } \\
-.706\end{array}$} & \multirow{3}{*}{$\begin{array}{c}\begin{array}{c}\text { Standard } \\
\text { Error } \\
\text { Límite } \\
\text { superior }\end{array} \\
.372\end{array}$} & \multirow{3}{*}{$\begin{array}{c}\begin{array}{c}\text { Sig. } \\
\text { Limite } \\
\text { inferior }\end{array} \\
.355\end{array}$} & \multicolumn{2}{|c|}{$\begin{array}{c}\text { Confidende interval } \\
\text { at } 95 \%\end{array}$} \\
\hline & & & & & \multirow{2}{*}{$\begin{array}{c}\text { Upper } \\
\text { Limit } \\
-1.70\end{array}$} & \multirow{2}{*}{$\begin{array}{c}\begin{array}{c}\text { Lower } \\
\text { Limit }\end{array} \\
.28\end{array}$} \\
\hline None & Little & & & & & \\
\hline & Enough & $-2.044^{*}$ & .555 & .002 & -3.52 & -.57 \\
\hline & A lot & .611 & .778 & 1.000 & -1.46 & 2.68 \\
\hline \multirow[t]{3}{*}{ Little } & None & .706 & .372 & .355 & -.28 & 1.70 \\
\hline & Enough & -1.338 & .520 & .063 & -2.72 & .04 \\
\hline & A lot & 1.317 & .754 & .489 & -.69 & 3.32 \\
\hline \multirow[t]{3}{*}{ Enough } & None & $2.044^{*}$ & .555 & .002 & .57 & 3.52 \\
\hline & Little & 1.338 & .520 & .063 & -.04 & 2.72 \\
\hline & A lot & $2.656^{*}$ & .859 & .013 & .37 & 4.94 \\
\hline \multirow[t]{3}{*}{ A lot } & None & -.611 & .778 & 1.000 & -2.68 & 1.46 \\
\hline & Little & -1.317 & .754 & .489 & -3.32 & .69 \\
\hline & Enough & $-2.656(*)$ & .859 & .013 & -4.94 & -.37 \\
\hline
\end{tabular}

${ }^{*} p<.05$ 


\section{Conclusions}

Findings from this study focus on the relationship between religious variables and hopelessness. We hypothesized a negative relationship: more religiosity (self-definition as a believer, frequent Mass attendance, a lot of importance of God) would be related to a lower mean on the HS total score, and less religiosity (self-definition as a nonbeliever, no Mass attendance, no importance of God) would be related to a higher mean on the HS total score.

Results show that differences in religious self-definition and Mass attendance are not significant in the HS total score. In importance of God, comparisons between enough-none and enough-A lot are significant, but are not significant the comparisons between none-little, none-A lot, little-enough, and little-A lot. These results are partially contrary to expectations, considering that most previous studies showed that a personal self-definition as a believer, and the frequency of attendance to Mass (among other religious variables) are negatively related to hopelessness (and, consequently, to suicide risk) (Ellison, Boardman, Williams \& Jackson, 2001; Green \& Elliot, 2010; Lester \& Francis, 1993; Murphy, 1999; Taliaferro, Rienzo, Morgan, Miller \& Dodd, 2009).

Although differences are not significant, it should be noted that the most religious individuals (Practicing Catholics, followed by Non-practicing Catholics) show a higher mean rank on the HS than Indifferent and Atheists do, unlike previous research results. On the other hand, differences in Mass attendance are not linear on the HS (attending more or less is not significant), and the Occasional attendance shows the highest mean rank.

Only the differences between Enough-None importance of God, and Enough-A lot importance of God are significant, as noted above. The significant negative relationship between the importance of God and hopelessness is not linear (from None to A lot, or vice versa). Differences between Enough and Little are not statistically significant, nor between None and A lot, and this means that there are three "groups" of importance of God in their relationship with hopelessness: 1) None-A lot, 2) Little, and 3) Enough. This suggests the hypothesis that the hopelessness level could be conditioned by the strength of one's position regarding the importance of God in life, in the sense that a stronger position would relate to less hopelessness. None and A lot of importance are stronger personal positions than Enough and, consequently, those groups are related to lower means on the HS.

On the other hand, the importance of God could be considered as a not necessarily institutional variable, in contrast to religious self-definition (catholic, practicing/non-practicing: identification with a specific religious denomination or beliefs), and to Mass attendance (unequivocally institutional: commitment with a specific worship). However, the importance of God is significantly related to religious self-definition, and to Mass attendance. But Practicing Catholics are shared in nearby percentages in Little (25\%), Enough (40.62\%) and A lot (34.37\%) importance of God. And an important percentage of the Indifferent group considers that the importance of God is Little (but not none). In other words, the variable importance of God could be not radically conditioned by the individual's religious self-definition. The importance of God, although related to other religious features, could have a particular religious status, possibly less "institutional", more personal and independent of institutional expressions of religiosity (religious identity, church attendance). And, in this regard, we hypothesize that the most important factor would be the strength of the personal position towards the importance that God has in one's life (None and A lot are stronger than Enough, and both are related to lower HS scores in our study, as noted above). However, this question demands further investigation.

To summarize, religious self-definition and Mass attendance are not related to significant differences in the HS total score, unlike the importance of God. In the first two variables, the relation between religiosity and hopelessness is positive: the more "religiosity" (in the terms of this variable), the higher the hopelessness score. On the contrary, the relationship between the importance of God and hopelessness is negative. We suggest that importance of God in one's life is a source of hope in greater extent than both church attendance and religious selfdefinition. Could be that the importance of God in one's life has a sense more spiritual, related to the personal effort to find, sustain, and transform a relationship with the sacred (Pargament, 1997). So, it is important to distinguish between religiosity and spirituality measures, in order to verify their different relationship with hopelessness and, in general, with mental health.

There are certain limitations that need to be acknowledged and addressed regarding the present study, concerning the composition of the sample. First, the sample is composed mainly of women (although, as noted, gender differences in hopelessness were not significant). Second, participants are university students, so the sample is not representative of the general population. Third, the composition of the different categories in the religious variables is poorly balanced in terms of number of subjects, and there is no representation of other religions than Catholicism. Fourth, religion has been characterized by only three items, and it is not distinguished from spirituality.

Therefore we suggest, for future research, using a sample more diverse in composition; its especially interesting to include subjects of different religions, to check how they managed in particular feelings such as hopelessness, purpose of this study; the sample should be more proportionate in all analyzed variables and more representative of the general population; we suggest using larger scales on different dimensions of religious experience (e. g., Núñez, Moral \& Moreno, 2010), and using qualitative methodology to identify the significance for individuals to include religion in their lives, and how religion operates in their view of life and their hope for the future; finally, we suggest distinguishing religion and spiritua- 
lity as different, following relevant authors (Paloutzian \& Park, 2005). In connection with the later, it seems necessary to distinguish "institutional/personal", or "religiosity/spirituality", and to consider various aspects of religiosity, to better clarify the role as different dimensions in mental health in general, and in hopelessness in particular.

\section{References}

1. Beck, A. T. \& Steer, R. A. (1993). Hopelessnes Scale Manual. San Antonio, TX: Har-court Brace.

2. Beck, A. T. (1964). Thinking and depression: II. Theory and Therapy. Archives of General Psychiatry, 10, 561-571.

3. Beck, A. T. (1967). Depression. New York: Harper \& Row.

4. Beck, A. T. (1970). Cognitive Therapy. Nature and relation to behavior therapy. Behavior Therapy, 1, 184-200. http:// dx.doi.org/10.1016/S0005-7894(70)80030-2

5. Beck, A. T., Brown, G., Berchick, R. J., Stewart, B. L. \& Steer, R. A. (1990). Relation-ships between hopelessness and ultimate suicide: A replication with psychiatry outpatients. American Journal of Psychiatry, 147, 190-195.

6. Beck, A. T., Kovacs, M. \& Weissman, A. (1975). Hopelessness and suicidal behavior: An overview. Journal of the American Medical Association, 234, 1146-1149. http://dx.doi.org/10.1001/jama.234.11.1146

7. Beck, A. T., Steer, R. A., Beck, J. S. \& Newman, C. F. (1993). Hopelessness, depression, suicidal ideation and clinical diagnosis of depression. Suicide and Life-Threatening Behavior, 23, 139-145.

8. Beck, A. T., Steer, R. A., Kovacs, M. \& Garrison, B. (1985). Hopelessness and eventual suicide: A ten year prospective study of patients hospitalized with suicidal ideation. American Journal of Psychiatry, 142, 559-563.

9. Beck, A.T., Weissman, A., Lester, D. \& Trexler, L. (1974). The measurement of pessi-mism: The hopelessness scale. Journal of Consulting and Clinical Psychology, 42, 861865. http://dx.doi.org/10.1037/h0037562

10. Clarke, D. M. \& Kissane, D. W. (2002). Demoralization: Its phenomenology and impor-tance. The Australian and New Zealand Journal of Psychiatry, 36, 33-42. http://dx.doi. org/10.1046/j.1440-1614.2002.01086.x

11. Conner, K. R., Duberstein, P. R., Conwell, Y., Seidlitz L. \& Caine, E. D. (2001). Psychological vulnerability to completed suicide: A review of empirical studies. Suicide and Life-Threatening Behavior, 31, 367-385. http://dx.doi. org/10.1521/suli.31.4.367.22048

12. Dalgalarrondo, P. (2006). Relações entre duas dimensoes fundamentais da vida: saúde mental e religião. Revista Brasileira de Psiquiatria, 28, 177-178.

13. Ellison, C. G., Boardman, J. D., Williams, D. R. \& Jackson, J. S. (2001). Religious involvement, stress, and mental health: Findings from the 1995 Detroit Area Study. Social Forces, 80, 215-249. http://dx.doi.org/10.1353/ sof.2001.0063
14. Esposito, C., Spirito, A., Boergers, J. \& Donaldson, D. (2003). Affective, behavioral, and cognitive functioning in adolescents with multiple suicide attempts. Suicide and Life-Threatening Behavior, 33, 389-399. http://dx.doi. org/10.1521/suli.33.4.389.25231

15. Garrison, M. E. B., Marks, L. D., Lawrence, F. C. \& Braun, B. (2004). Religious be-liefs, faith, community involvement, and depression: A study of rural, low income mothers. Women Health, 40, 51-62. http://dx.doi.org/10.1300/ J013v40n03 04

16. George, L. K., Larson, D. B., Koenig, H. G. \& McCullogh, M. E. (2000). Spirituality and health: What we know, what we need to know. Journal of Social and Clinical Psychology, 19, 102-116. http://dx.doi.org/10.1521/jscp.2000.19.1.102

17. Green, M. \& Elliot, M. (2010). Religion, Health, and Psychological Well-Being. Journal of Religion and Health, 49, 149-163. http://dx.doi.org/10.1007/s10943-009-9242-1

18. Grey, E. (2005). Religious involvement, religious coping and suicidogenic factors in African-American high school students. Dissertation Abstracts International, 66(1-B), 552.

19. Hammermeister, J., Flint, M., Havens, J. \& Peterson, M. (2001). Pyschosocial and health-related characteristics of religious well-being. Psychological Reports, 89, 589-594.

20. Hill, T. D., Angel, J. L., Ellison, C. G. \& Angel, R. J. (2005). Religious attendance and mortality: An 8-year follow-up of Mexican Americans. The Journals of Gerontology Series B: Psychological Sciences and Social Sciences, 60, 102109. http://dx.doi.org/10.1093/geronb/60.2.S102

21. Koenig, H. G. (1997). Is religion good for your health? The effects of religion on physical and mental health. Binghamton, NY: Haworth Press.

22. Koenig, H. G. (2007). Religião, espiritualidade e psiquiatria: uma nova era na atenção à saúde mental. Revista de Psiquiatria Clínica, 34, 5-7.

23. Lester, D. \& Francis, L. J. (1993). Is religiosity related to suicidal ideation after person-ality and mod are taken into account? Personality and Individual Differences, 15, 591592. http://dx.doi.org/10.1016/0191-8869(93)90342-Z

24. Moreira-Almeida, A., Lotufo Neto, F. \& Koenig, H. G. (2006). Religiousness and men-tal health: a review. Revista Brasileira de Psiquiatria, 28, 242-250. http://dx.doi. org/10.1590/S1516-44462006005000006

25. Murphy, P. E. (1999). A longitudinal analysis of the impact of religion on the experi-ence of depression and hopelessness in a clinical simple. Dissertation Abstracts International, 59, 4477.

26. Núñez, M., Moral, F. \& Moreno, M. P. (2010). Impacto diferencial de la religión en el prejuicio entre muestras cristianas y musulmanas. Escritos de Psicología, 3, 11-20.

27. Pargament, K. I. (1997). The Psychology of Religion and Coping: Theory, Research, Practice. New York: Guilford Publications. 
28. Pargament, K. I., Koenig, H. G. \& Perez L. M. (2000). The Many Methods of Religious Coping: Development and Initial Validation of the RCOPE. Journal of Clinical Psychology, 56, 519-543. http://dx.doi. org/10.1002/(SICI)1097-4679(200004)56:4<519::AIDJCLP6>3.0.CO;2-1

29. Paulotzian, R. F. \& Park, C. L. (2005). Handbook of the Psychology of Religion and Spirituality. New York: Guilford Press.

30. Quintanilla, R., Haro, L. P., Flores, M. E., Celis, A. \& Valencia, S. (2003). Desesperanza y tentativa suicida. Invest Salud. [Online] Available from: http://redalyc.uaemex.mx/ redalyc/src/inicio/ArtPdfRed.jsp?iCve $=14250206$

31. Simonson, R. H. (2008). Religiousness and non-hopeless suicide ideation. Death Studies, 32, 951-960. http://dx.doi. org/10.1080/07481180802440589

32. Smith, T. B., McCullogh, M. E. \& Poll, J. (2003). Religiousness and depression: Evidence for a main effect and the moderating influence of stressful life events. Psychological Bulletin, 129, 614-636. http://dx.doi. org/10.1037/0033-2909.129.4.614
33. Taliaferro, L. A., Rienzo, B. A., Morgan, R., Miller, M. D. \& Dodd, V. J. (2009). Spiritual Well-Being and Suicidal Ideation Among College Students. Journal of American College Health, 8, 83-90. http://dx.doi.org/10.3200/ JACH.58.1.83-90

34. Viñas, F., Villar, E., Caparrós, B., Juan, J., Cornellá, M. \& Pérez, I. (2004). Feelings of hopelessness in a Spanish university population. Descriptive analysis and its relationship to adapting to university, depressive symptomatology and suicidal ideation. Social Psychiatry and Psychiatric Epidemiology, 39, 326-334.

Received 15 March 2011 Received in revised form 1 September 2011 Accepted 19 September 2011 